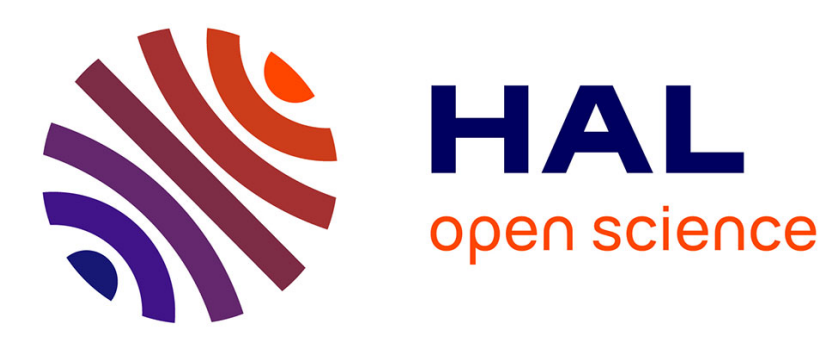

\title{
Stretching skeletal muscle in vitro: does it replicate in vivo physiology?
}

S. Passey, N. Martin, D. Player, M. P. Lewis

\section{To cite this version:}

S. Passey, N. Martin, D. Player, M. P. Lewis. Stretching skeletal muscle in vitro: does it replicate in vivo physiology?. Biotechnology Letters, 2011, 33 (8), pp.1513-1521. 10.1007/s10529-011-0610-z . hal-00686171

\section{HAL Id: hal-00686171 \\ https://hal.science/hal-00686171}

Submitted on 8 Apr 2012

HAL is a multi-disciplinary open access archive for the deposit and dissemination of scientific research documents, whether they are published or not. The documents may come from teaching and research institutions in France or abroad, or from public or private research centers.
L'archive ouverte pluridisciplinaire HAL, est destinée au dépôt et à la diffusion de documents scientifiques de niveau recherche, publiés ou non, émanant des établissements d'enseignement et de recherche français ou étrangers, des laboratoires publics ou privés. 


\section{Section: Review}

\section{Stretching skeletal muscle in vitro: does it replicate in vivo physiology?}

S. Passey, N. Martin, D. Player, M.P. Lewis

Muscle Cellular and Molecular Physiology Research Group, ISPAR Bedford, University of Bedfordshire, MK41 9EA

Author for Correspondence:

Professor Mark Lewis

Muscle Cellular and Molecular Physiology Research Group, ISPAR Bedford, University of Bedfordshire, MK41 9EA

E-mail: Mark.Lewis@beds.ac.uk 


\begin{abstract}
Skeletal muscle is highly adaptable and responds to changes in loading through exercise or resistance training through a number of mechanisms resulting in increased muscle mass and changes in contractile phenotype. To further understand and study the molecular mechanisms underlying the adaptive response of muscle, a number of in vitro culture systems have been developed that utilise mechanical loading or stretching of the cultured muscle to recapitulate the adaptations observed in vivo. Here we review the use of such stretching regimes for engineered muscle constructs and assess how well these in vitro systems mimic in vivo muscle physiology and adaptation.
\end{abstract}

Keywords: skeletal muscle model, stretch protocol, tissue engineering,

\title{
Introduction
}

Skeletal muscle tissue possesses a high degree of plasticity in that it has the ability to adapt specifically to the functional demands placed upon it or alterations in its environment by responding, for example, to changes in the levels of growth factors and cytokines or to changes in neuronal stimulation or mechanical loading such as is experienced during exercise or resistance training. At the physiological level, the muscle responds to such stimuli through increasing the synthesis of numerous proteins important for muscle contraction and metabolism to allow for the increased workload, leading to muscle hypertrophy. Various 
additional stimuli such as the availability of amino acids have been shown to potentiate this adaptive response (Norton and Layman 2006; Dreyer et al. 2008; Tipton et al. 2009).

The study of the molecular mechanisms underlying muscle adaptation has traditionally relied on the use of human subjects and animal models. Studies using in vivo systems prove difficult for many reasons; and it has been suggested that the molecular responses observed in existing in vivo models may not accurately mimic the normal physiological muscle adaptation to exercise training (Spangenburg 2009). For these reasons, suitable in vitro model systems that recapitulate the in vivo conditions and allow for accurate control of the experimental environment are highly desirable to allow detailed study of the molecular mechanisms of muscle adaptation and development.

Over the last 30 years, a number of in vitro model systems have been developed that show some similarities with muscle in vivo. The aim of this paper is to review the body of literature that have used these muscle stretching techniques, with reference to the ability of such regimes to mimic the effects seen in skeletal muscle in vivo.

\section{In vitro skeletal muscle models}

Skeletal muscle in vivo is formed of groups of myofibres attached to tendons longitudinally, and surrounded by a connective tissue matrix (Mastaglia and Walton 1982). Under normal physiological conditions the muscle fibres experience force in a longitudinal direction during embryogenesis and growth, and also during exercise or resistance training. It goes to follow that an ideal muscle stretching system would look to mimic the forces experienced by the 
muscle fibres in vitro and so would ideally exert uniaxial forces on the cultured cells. However the different types of stretching systems available differ in producing uniaxial or multiaxial stretch, as illustrated in Figure 1A. Indeed the direction of the stretch forces is an important feature to consider when investigating muscle responses to strain, as it has been demonstrated that the signalling pathways activated differ in response to multiaxial vs. uniaxial stretch (Hornberger et al. 2005).

\section{Figure 1 to be inserted here}

The first-reported in vitro stretching model employed by Vandenburgh and Kaufman consisted of a stretching frame surrounding an elastic membrane on which chicken skeletal muscle myoblasts were plated and differentiated to form early myotubes in two dimensions, whilst being stretched under the multiaxial strain produced by the stretching frame (Vandenburgh and Kaufman 1979).

Work from the same laboratory further developed the Vandenburgh system through the addition of a computer controlled stepper motor (Vandenburgh 1988), which allowed the generation of various cyclical and ramp loading protocols (Figure 1B) that are used to model different strain types that skeletal muscles would be exposed to in vivo. The ability to vary the stretching protocols expanded the use of this system to mimic the effects of exercise, resistance training and growth and allow the study of the effects of different loading regimes on muscle physiology and the hypertrophy response. A similar system used by Iwata and colleagues uses a programmable motor to exert a uniaxial stretch on muscle cells cultured in 2D on an elastic silicone membrane (Iwata et al. 2007). 
In the commercially available Flexercell system (Flexcell International Corporation, Hillsborough, NC, USA), cells are grown on flexible culture plates in two dimensions, which are deformed and stretched by a vacuum controlled by a computer, allowing varying regimens of strain to be employed (Hubatsch and Jasmin 1997).

Muscle cells in vivo grow and differentiate in a 3-dimensional environment and their development is greatly influenced by the signals they receive from the surrounding cells and extracellular matrix (ECM) components. A number of 3D biomimetic model systems have been described with the intention of recreating aspects of the $3 \mathrm{D}$ environment and so promoting the formation of physiological muscle models. Such models include the use of collagen gel matrices (Powell et al. 2002; Cheema et al. 2003), or collagen gel foam sponges (Auluck et al. 2005) to provide a physiologically relevant matrix into which the muscle cells are seeded. Muscle constructs grown in such a 3D environment under uniaxial strain have been shown to exhibit a slow phenotype analogous to that of postural muscle in vivo (Mudera et al. 2010).

\section{Alterations in muscle phenotype and metabolism}

\section{Hypertrophy}

Skeletal muscle responds to increased load from resistance training or exercise through various physiological and molecular adaptations including increases in protein synthesis leading to muscle hypertrophy. Typically increases in muscle cross sectional area are observed in humans following resistance training programmes of six to sixteen weeks 
duration, with the extent of hypertrophy from $7.5 \%$ to $25 \%$ depending on the study participants, muscle type studied and exercise regime (McCall et al. 1996; Kosek et al. 2006; Holm et al. 2008; Friedmann-Bette et al. 2010). In vivo animal studies have also demonstrated robust hypertrophic responses to muscle loading (Goldberg 1967; Goldspink et al. 1995).

Using the Vandenburgh model, the myotube diameter and creatine kinase activity both increase following in vitro stretching, indicating that similar hypertrophy responses are initiated by stretching using in vitro systems (Vandenburgh and Kaufman 1979; Vandenburgh et al. 1989). In vivo exercise also increases serum creatine kinase activity which tends to be most pronounced after eccentric muscle loading (Nosaka and Clarkson 1996; Nosaka et al. 2002).

Using their 3D collagen gel system, Powell et al. (2002) introduced cyclical stretching protocols to differentiated myotubes with $12 \%$ myotube hypertrophy being observed; again this data is comparable to muscle hypertrophy observed in vivo in response to exercise training.

Signalling through mTOR is required for the hypertrophy response (Leger et al. 2006; Miyazaki and Esser 2009; Dreyer et al. 2010) and in vitro stretching systems have been used to further investigate the molecular mechanisms of mTOR activation and signalling. Using the Iwata and Flexercell systems, similar involvement of the mTOR signalling pathway in the hypertrophy response to stretch has been observed following muscle stretch in $\mathrm{C} 2 \mathrm{C} 12$ cells and in primary chick skeletal myotubes (Hornberger et al. 2004; Sasai et al. 2010). 
The rate of protein synthesis in muscle in vivo actually decreases during exercise (BylundFellenius et al. 1984; Dreyer et al. 2006), and then increases again following exercise, an effect that is potentiated by increased availability of carbohydrate and amino acids (Tipton et al. 2009). This effect has also been observed in vitro using the Flexercell system to apply stretch to L6 rat muscle cells, resulting in a suppression of myofibrillar protein synthesis by $40 \%$ over the initial 30 minute period which then returned to baseline at later timepoints (Atherton et al. 2009).

\section{Neuromuscular adaptation}

In addition to structural adaptations and hypertrophy of the muscle fibres themselves, some aspects of muscle adaptation in response to exercise are related to improved neuromuscular function and neural adaptation leading to improvements in muscle function (Folland and Williams 2007). For example, increased activity of acetylcholinesterase (AchE) in the neuromuscular junction is observed in vivo in rats following exercise training or muscle overload protocols (Jasmin et al. 1991; Sveistrup et al. 1995). Interestingly, in vitro studies using the Flexercell muscle stretching system have shown similar increases in AchE mRNA and protein following cyclical stretching protocols (Hubatsch and Jasmin 1997). Whilst the mechanism for this increase is not yet known, these alterations in the levels of neuromuscular junction proteins further suggest an adaptive response to exercise and stretch in vitro that mirrors that seen in vivo.

\section{Myosin heavy chain composition}


Skeletal muscle is heterogeneous in that it is composed of both fast and slow twitch muscle fibres, so-named on the basis of their contractile and metabolic phenotype. Fast twitch myofibres express type II Myosin Heavy Chain (MHC) isoforms and show a high contraction velocity, whereas slow-twitch fibres express Type I MHC isoforms and exhibit slower contraction velocities (Bassel-Duby and Olson 2006). The muscle fibre type found in an individual muscle relates to the physiological function of the muscle and the physical demands placed on it, and is also determined by the neuronal input the muscle receives (Salmons and Sreter 1976).

Human studies have demonstrated adaptive changes in MHC expression and phenotype in response to exercise, with a shift from fast MHC isoforms to slower isoforms being observed in response to endurance, resistance and even sprint training (Jansson and Kaijser 1977;

Hather et al. 1991; Coggan et al. 1992; Adams et al. 1993; Allemeier et al. 1994; Staron et al. 1994). Similar shifts in MHC expression have been observed in response to stretch in vitro using the Flexercell system, where a shift from the faster MHC IIb to the IIa and even MHC I isoforms was observed with increased stretch (Sakiyama et al. 2005; Kurokawa et al. 2007).

\section{Glucose metabolism}

Skeletal muscle is the major tissue involved in glucose uptake and homeostasis in vivo (Abdul-Ghani and DeFronzo 2010), and an increase in glucose uptake by the muscle is observed during exercise in vivo (Rose and Richter 2005) and in vitro. Hatfaludy et al, observed increases in both glucose uptake and lactate efflux by muscle cultures subjected to stretch-relaxation protocols using the Vandenburgh system (Hatfaludy et al. 1989) and Iwata et al. also described a calcium-dependent mechanism for glucose uptake by skeletal muscle 
cells following in vitro stretch (Iwata et al. 2007). In agreement with these results, evidence for calcium mediated glucose uptake following exercise in vivo is well documented (Santos et al. 2008).

\section{Muscle repair and regeneration}

\section{Growth factors and satellite cell activation}

In vitro studies have also helped to increase our understanding of how muscle is repaired following acute muscle damage, such as may occur with active muscle stretch. Muscle repair and regeneration is thought to occur via the activation of muscle resident satellite cells; skeletal muscle stem cells which upon activation can differentiate to form myoblasts and can fuse with existing myofibres (Seale and Rudnicki 2000).

Activation of satellite cells has been demonstrated in vivo following a bout of electrical stimulation (Mackey et al. 2009) and prevention of satellite cell proliferation through exposure to $\gamma$-irradiation has also been shown to inhibit muscle hypertrophy in rats, demonstrating a role for satellite cells in contributing nuclei to myofibres as part of the hypertrophy response (Rosenblatt et al. 1994).

Using the Flexercell system, satellite cell activation has been demonstrated in both single muscle fibres (Wozniak et al. 2003) and in cultured muscle cell lines as early as 2 hours poststretch (Tatsumi et al. 2001). Hepatocyte growth factor (HGF) was identified as an important activator of satellite cells, as demonstrated by the observation of a dose-dependent decrease 
in the level of satellite cell activation in response to mechanical stretch with increasing concentrations of a blocking anti-HGF antibody(Tatsumi et al. 2001). These results shed more light on the in vivo findings that direct injection of HGF into uninjured muscle of rats stimulates satellite cell activation (Tatsumi et al. 1998) and resistance training induces increases in serum HGF protein levels (Shelmadine et al. 2009).

Activation of satellite cells is regulated by various other growth factors, of which the splice variants of insulin-like growth factor 1 (IGF-1) appear to be of great importance. In vivo studies have shown mRNA levels of the IGF-1 splice variant mechano-growth factor (MGF, also known as IGF-1Ec in humans) to peak early after muscle damage/stretch, implicating MGF in the activation of muscle resident satellite cells (Hill and Goldspink 2003; McKay et al. 2008). These data are supported by similar observations in vitro, where increased levels of MGF mRNA have been observed in the 3D collagen model following stretch (Cheema et al. 2005).

\section{Satellite cells and matrix remodelling}

It is becoming increasingly obvious that muscle repair and satellite cell activation requires interaction with and remodelling of the surrounding matrix. These processes that are mediated by the matrix metalloproteinases (MMPs) and a number of in vivo studies have revealed that changes in MMP expression and activity accompany muscle repair and remodelling. A biphasic pattern of MMP expression in response to exercise or muscle damage has been described, beginning with an early increase in MMP-9 mRNA and protein levels immediately post exercise and followed by a later increase in MMP-2 levels (Rullman et al. 2007, 2009; Zimowska et al. 2008; ). 
In support of the in vivo findings, Lewis et al. (2000) showed that, in 2D, developing skeletal muscle exhibited MMP-2 activity throughout a 14 day culture, whereas MMP-9 activity was only present in an early culture (days 2-4). Similarly, using the 3D collagen system, MMP-2 activity increased following stretching in a load-dependent manner (Auluck et al. 2005).

Balancing the ECM-degrading activity of the MMPs is a family of inhibitor proteins, the tissue inhibitors of metalloproteinases (TIMPs) and, interestingly, an increase in TIMP-1 mRNA levels occurs at later time points following exercise, both in vivo (Rullman et al. 2009) and in vitro as the skeletal muscle constructs matured (Lewis et al. 2000). This led to the suggestion that the early increase in MMP activity enabled ECM remodelling and satellite cell migration, and that at later times TIMP-1 expression increased to balance the actions of the MMPs (Lewis et al. 2000). This is further supported by additional in vitro data from Yamada et al. (2006) who demonstrated that the addition of TIMP-1 to the culture medium of cells during stretching with the Flexercell system attenuated HGF release and satellite cell activation.

\section{Molecular regulation of satellite cells}

The myogenic regulatory factors (MRFs) are a group of transcription factors that lie at the heart of skeletal muscle regeneration and myogenic differentiation, and consist of myf-5, MyoD, myogenin and MRF 4. At early stages of satellite cell activation myf-5 and MyoD are required, whereas myogenin and MRF4 appear to be involved at later points in the differentiation process (Cornelison and Wold 1997). 
In vivo studies support the role of the MRFs in satellite cell activation, proliferation and differentiation; MyoD expression peaked at early points following exercise/muscle stimulation whereas myogenin expression peaked later (Bickel et al. 2005; McKay et al. 2008). In vitro experiments have given comparable results: the genes MyoD and myf-5 were up-regulated early in the stretching process (first $12 \mathrm{~h}$ ), whereas myogenin and MRF-4 were up regulated after $24 \mathrm{~h}$ of stretching before returning to control levels thereafter (Abe et al. 2009).

Boonen et al. (2010), however, have presented seemingly contradictory results for the effects of stretching on muscle maturation and regeneration. Using both $\mathrm{C} 2 \mathrm{C} 12$ cells and primary muscle precursor cells (MPCs) cultured either in 2D or in 3D fibrin-based constructs, the authors observed a decrease in MRF expression following intermittent stretching protocols performed using the FlexCell system. A decrease in muscle maturation was also described, determined by a reduction in the development of cross-striations and MHC mRNA transcripts in the stretched MPCs compared to static controls (Boonen et al. 2010). The strain levels used in this study were lower than those commonly used for in vitro stretching studies (Sakiyama et al. 2005; Kurokawa et al. 2007) and this may explain some of the discrepancies between this data and other publications. The existence of such apparently contradictory data highlights the importance of further work to fully optimise in vitro muscle stretching systems, as many aspects including the cell culture matrix and environment (2D vs. 3D), the extent and speed of stretching and the duration of stretch are all likely to affect the adaptive responses of the cells and their maturation into functional muscle models.

Table 1 to be inserted here. 


\section{Conclusions.}

Here we have briefly reviewed a range of in vitro engineered skeletal muscle models that utilise stretch regimes to mechanically exercise the muscle tissue in order to study the adaptive responses. Much progress has been made in developing such models, and already the application of such in vitro systems is helping to expand our understanding of muscle function and adaptation at the molecular level and compliment the findings of in vivo studies (summarised in Table 1).

It is an exciting time for muscle tissue engineering. In addition to further optimising the stretching regimes employed to mimic the physiological environment, future work will most likely aim to generate increasingly sophisticated human and mammalian muscle constructs and the integration of other aspects such as neuronal inputs. Future work in the field will be applying these in vitro muscle systems to delve ever deeper into the molecular world that governs muscle adaptation, repair and regeneration.

Abdul-Ghani, M. A. and R. A. DeFronzo (2010). "Pathogenesis of insulin resistance in skeletal muscle." J Biomed Biotechnol 2010: 476279.

Abe, S., S. Rhee, et al. (2009). "Effect of mechanical stretching on expressions of muscle specific transcription factors MyoD, Myf-5, myogenin and MRF4 in proliferated myoblasts." Anat Histol Embryol 38(4): 305-310. 
Adams, G. R., B. M. Hather, et al. (1993). "Skeletal muscle myosin heavy chain composition and resistance training." J Appl Physiol 74(2): 911-915.

Allemeier, C. A., A. C. Fry, et al. (1994). "Effects of sprint cycle training on human skeletal muscle." J Appl Physiol 77(5): 2385-2390.

Atherton, P. J., N. J. Szewczyk, et al. (2009). "Cyclic stretch reduces myofibrillar protein synthesis despite increases in FAK and anabolic signalling in L6 cells." $\underline{\mathrm{J} \text { Physiol }}$ 587(Pt 14): 3719-3727.

Auluck, A., V. Mudera, et al. (2005). "A three-dimensional in vitro model system to study the adaptation of craniofacial skeletal muscle following mechanostimulation." Eur J Oral Sci 113(3): 218-224.

Bassel-Duby, R. and E. N. Olson (2006). "Signaling pathways in skeletal muscle remodeling." Annu Rev Biochem 75: 19-37.

Bickel, C. S., J. Slade, et al. (2005). "Time course of molecular responses of human skeletal muscle to acute bouts of resistance exercise." J Appl Physiol 98(2): 482-488.

Boonen, K. J., M. L. Langelaan, et al. (2010). "Effects of a combined mechanical stimulation protocol: Value for skeletal muscle tissue engineering." J Biomech 43(8): 1514-1521.

Bylund-Fellenius, A. C., K. M. Ojamaa, et al. (1984). "Protein synthesis versus energy state in contracting muscles of perfused rat hindlimb." Am J Physiol 246(4 Pt 1): E297305.

Cheema, U., R. Brown, et al. (2005). "Mechanical signals and IGF-I gene splicing in vitro in relation to development of skeletal muscle." J Cell Physiol 202(1): 67-75.

Cheema, U., S. Y. Yang, et al. (2003). "3-D in vitro model of early skeletal muscle development." Cell Motil Cytoskeleton 54(3): 226-236.

Coggan, A. R., R. J. Spina, et al. (1992). "Skeletal muscle adaptations to endurance training in 60- to 70-yr-old men and women." J Appl Physiol 72(5): 1780-1786. 
Cornelison, D. D. and B. J. Wold (1997). "Single-cell analysis of regulatory gene expression in quiescent and activated mouse skeletal muscle satellite cells." Dev Biol 191(2): 270-283.

Dreyer, H. C., M. J. Drummond, et al. (2008). "Leucine-enriched essential amino acid and carbohydrate ingestion following resistance exercise enhances mTOR signaling and protein synthesis in human muscle." Am J Physiol Endocrinol Metab 294(2): E392400.

Dreyer, H. C., S. Fujita, et al. (2006). "Resistance exercise increases AMPK activity and reduces $4 \mathrm{E}-\mathrm{BP} 1$ phosphorylation and protein synthesis in human skeletal muscle." $\mathrm{J}$ Physiol 576(Pt 2): 613-624.

Dreyer, H. C., S. Fujita, et al. (2010). "Resistance exercise increases leg muscle protein synthesis and mTOR signalling independent of sex." Acta Physiol (Oxf) 199(1): 7181.

Folland, J. P. and A. G. Williams (2007). "The adaptations to strength training : morphological and neurological contributions to increased strength." Sports Med 37(2): 145-168.

Friedmann-Bette, B., T. Bauer, et al. (2010). "Effects of strength training with eccentric overload on muscle adaptation in male athletes." Eur J Appl Physiol 108(4): 821-836.

Goldberg, A. L. (1967). "Work-induced growth of skeletal muscle in normal and hypophysectomized rats." Am J Physiol 213(5): 1193-1198.

Goldspink, D. F., V. M. Cox, et al. (1995). "Muscle growth in response to mechanical stimuli." Am J Physiol 268(2 Pt 1): E288-297.

Hatfaludy, S., J. Shansky, et al. (1989). "Metabolic alterations induced in cultured skeletal muscle by stretch-relaxation activity." Am J Physiol 256(1 Pt 1): C175-181. 
Hather, B. M., P. A. Tesch, et al. (1991). "Influence of eccentric actions on skeletal muscle adaptations to resistance training." Acta Physiol Scand 143(2): 177-185.

Hill, M. and G. Goldspink (2003). "Expression and splicing of the insulin-like growth factor gene in rodent muscle is associated with muscle satellite (stem) cell activation following local tissue damage." J Physiol 549(Pt 2): 409-418.

Holm, L., S. Reitelseder, et al. (2008). "Changes in muscle size and MHC composition in response to resistance exercise with heavy and light loading intensity." J Appl Physiol 105(5): 1454-1461.

Hornberger, T. A., D. D. Armstrong, et al. (2005). "Intracellular signaling specificity in response to uniaxial vs. multiaxial stretch: implications for mechanotransduction." Am J Physiol Cell Physiol 288(1): C185-194.

Hornberger, T. A., R. Stuppard, et al. (2004). "Mechanical stimuli regulate rapamycinsensitive signalling by a phosphoinositide 3-kinase-, protein kinase B- and growth factor-independent mechanism." Biochem J 380(Pt 3): 795-804.

Hubatsch, D. A. and B. J. Jasmin (1997). "Mechanical stimulation increases expression of acetylcholinesterase in cultured myotubes." Am J Physiol 273(6 Pt 1): C2002-2009.

Iwata, M., K. Hayakawa, et al. (2007). "Uniaxial cyclic stretch-stimulated glucose transport is mediated by a ca-dependent mechanism in cultured skeletal muscle cells." Pathobiology 74(3): 159-168.

Jansson, E. and L. Kaijser (1977). "Muscle adaptation to extreme endurance training in man." Acta Physiol Scand 100(3): 315-324.

Jasmin, B. J., P. F. Gardiner, et al. (1991). "Muscle acetylcholinesterase adapts to compensatory overload by a general increase in its molecular forms." J Appl Physiol 70(6): 2485-2489. 
Kosek, D. J., J. S. Kim, et al. (2006). "Efficacy of 3 days/wk resistance training on myofiber hypertrophy and myogenic mechanisms in young vs. older adults." $\underline{\mathrm{J} \text { Appl Physiol }}$ 101(2): 531-544.

Kurokawa, K., S. Abe, et al. (2007). "Effects of stretching stimulation with different rates on the expression of MyHC mRNA in mouse cultured myoblasts." Biomed Res 28(1): 25-31.

Leger, B., R. Cartoni, et al. (2006). "Akt signalling through GSK-3beta, mTOR and Foxo1 is involved in human skeletal muscle hypertrophy and atrophy." J Physiol 576(Pt 3): 923-933.

Lewis, M. P., H. L. Tippett, et al. (2000). "Gelatinase-B (matrix metalloproteinase-9; MMP9) secretion is involved in the migratory phase of human and murine muscle cell cultures." J Muscle Res Cell Motil 21(3): 223-233.

Mackey, A. L., M. Kjaer, et al. (2009). "Assessment of satellite cell number and activity status in human skeletal muscle biopsies." Muscle Nerve 40(3): 455-465.

Mastaglia, F. L. and J. Walton (1982). Skeletal Muscle Pathology. New York, Churchill Livingstone.

McCall, G. E., W. C. Byrnes, et al. (1996). "Muscle fiber hypertrophy, hyperplasia, and capillary density in college men after resistance training." J Appl Physiol 81(5): 20042012.

McKay, B. R., C. E. O'Reilly, et al. (2008). "Co-expression of IGF-1 family members with myogenic regulatory factors following acute damaging muscle-lengthening contractions in humans." J Physiol 586(Pt 22): 5549-5560.

Miyazaki, M. and K. A. Esser (2009). "Cellular mechanisms regulating protein synthesis and skeletal muscle hypertrophy in animals." J Appl Physiol 106(4): 1367-1373. 
Norton, L. E. and D. K. Layman (2006). "Leucine regulates translation initiation of protein synthesis in skeletal muscle after exercise." J Nutr 136(2): 533S-537S.

Nosaka, K. and P. M. Clarkson (1996). "Variability in serum creatine kinase response after eccentric exercise of the elbow flexors." Int J Sports Med 17(2): 120-127.

Nosaka, K., M. Newton, et al. (2002). "Delayed-onset muscle soreness does not reflect the magnitude of eccentric exercise-induced muscle damage." $\underline{\text { Scand J Med Sci Sports }}$ 12(6): 337-346.

Powell, C. A., B. L. Smiley, et al. (2002). "Mechanical stimulation improves tissueengineered human skeletal muscle." Am J Physiol Cell Physiol 283(5): C1557-1565.

Rose, A. J. and E. A. Richter (2005). "Skeletal muscle glucose uptake during exercise: how is it regulated?" Physiology (Bethesda) 20: 260-270.

Rosenblatt, J. D., D. Yong, et al. (1994). "Satellite cell activity is required for hypertrophy of

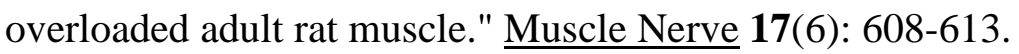

Rullman, E., J. Norrbom, et al. (2009). "Endurance exercise activates matrix metalloproteinases in human skeletal muscle." J Appl Physiol 106(3): 804-812.

Rullman, E., H. Rundqvist, et al. (2007). "A single bout of exercise activates matrix metalloproteinase in human skeletal muscle." J Appl Physiol 102(6): 2346-2351.

Sakiyama, K., S. Abe, et al. (2005). "Effects of stretching stress on the muscle contraction proteins of skeletal muscle myoblasts." Biomed Res 26(2): 61-68.

Salmons, S. and F. A. Sreter (1976). "Significance of impulse activity in the transformation of skeletal muscle type." Nature 263(5572): 30-34.

Santos, J. M., S. B. Ribeiro, et al. (2008). "Skeletal muscle pathways of contraction-enhanced glucose uptake." Int J Sports Med 29(10): 785-794.

Sasai, N., N. Agata, et al. (2010). "Involvement of PI3K/Akt/TOR pathway in stretchinduced hypertrophy of myotubes." Muscle Nerve 41(1): 100-106. 
Seale, P. and M. A. Rudnicki (2000). "A new look at the origin, function, and "stem-cell" status of muscle satellite cells." Dev Biol 218(2): 115-124.

Shelmadine, B., M. Cooke, et al. (2009). "Effects of 28 days of resistance exercise and consuming a commercially available pre-workout supplement, NO-Shotgun(R), on body composition, muscle strength and mass, markers of satellite cell activation, and clinical safety markers in males." J Int Soc Sports Nutr 6: 16.

Spangenburg, E. E. (2009). "Changes in muscle mass with mechanical load: possible cellular mechanisms." Appl Physiol Nutr Metab 34(3): 328-335.

Staron, R. S., D. L. Karapondo, et al. (1994). "Skeletal muscle adaptations during early phase of heavy-resistance training in men and women." J Appl Physiol 76(3): 1247-1255.

Sveistrup, H., R. Y. Chan, et al. (1995). "Chronic enhancement of neuromuscular activity increases acetylcholinesterase gene expression in skeletal muscle." Am J Physiol 269(4 Pt 1): C856-862.

Tatsumi, R., J. E. Anderson, et al. (1998). "HGF/SF is present in normal adult skeletal muscle and is capable of activating satellite cells." Dev Biol 194(1): 114-128.

Tatsumi, R., S. M. Sheehan, et al. (2001). "Mechanical stretch induces activation of skeletal muscle satellite cells in vitro." Exp Cell Res 267(1): 107-114.

Tipton, K. D., T. A. Elliott, et al. (2009). "Stimulation of muscle anabolism by resistance exercise and ingestion of leucine plus protein." Appl Physiol Nutr Metab 34(2): 151161.

Vandenburgh, H. and S. Kaufman (1979). "In vitro model for stretch-induced hypertrophy of skeletal muscle." Science 203(4377): 265-268.

Vandenburgh, H. H. (1988). "A computerized mechanical cell stimulator for tissue culture: effects on skeletal muscle organogenesis." In Vitro Cell Dev Biol 24(7): 609-619. 
Vandenburgh, H. H., S. Hatfaludy, et al. (1989). "Skeletal muscle growth is stimulated by intermittent stretch-relaxation in tissue culture." Am J Physiol 256(3 Pt 1): C674-682.

Wozniak, A. C., O. Pilipowicz, et al. (2003). "C-Met expression and mechanical activation of satellite cells on cultured muscle fibers." J Histochem Cytochem 51(11): 1437-1445.

Yamada, M., R. Tatsumi, et al. (2006). "Matrix metalloproteinases are involved in mechanical stretch-induced activation of skeletal muscle satellite cells." Muscle Nerve 34(3): 313-319.

Zimowska, M., E. Brzoska, et al. (2008). "Distinct patterns of MMP-9 and MMP-2 activity in slow and fast twitch skeletal muscle regeneration in vivo." Int J Dev Biol 52(2-3): 307-314. 
Table 1: Comparison of findings from in vivo studies and in vitro muscle stretching studies.

\begin{tabular}{|c|c|c|c|c|c|}
\hline Measure & In vivo & In vitro & $\begin{array}{l}\text { In vivo } \\
\text { References }\end{array}$ & $\begin{array}{l}\text { In vitro } \\
\text { References }\end{array}$ & $\begin{array}{l}\text { In vitro } \\
\text { stretch } \\
\text { protocol }\end{array}$ \\
\hline \multirow[t]{3}{*}{$\begin{array}{l}\text { Myofibre } \\
\text { diameter }\end{array}$} & \multirow[t]{3}{*}{$\uparrow$} & \multirow[t]{3}{*}{$\uparrow$} & \multirow[t]{3}{*}{$\begin{array}{l}\text { McCall et al. 1996, } \\
\text { Hom et al. (2008). }\end{array}$} & $\begin{array}{l}\text { Vandenburgh et } \\
\text { al. (1989a) }\end{array}$ & $\begin{array}{l}\text { Cyclical } 20 \% \\
\text { or } 46 \% \text { for up } \\
\text { to } 96 \mathrm{~h} \text {. }\end{array}$ \\
\hline & & & & $\begin{array}{l}\text { Powell et al. } \\
(2002)\end{array}$ & $\begin{array}{l}\text { Ramp } 10 \% \\
\text { then cyclical } \\
5 / 10 / 15 \% \\
\text { over } 8 \text { days. }\end{array}$ \\
\hline & & & & Sasai et al. (2009) & $\begin{array}{l}\text { Cyclical } 10 \% \text { at } \\
0.16 \mathrm{~Hz} \text { for } 72 \mathrm{~h}\end{array}$ \\
\hline $\begin{array}{l}\text { Creatine } \\
\text { Kinase } \\
\text { release }\end{array}$ & $\uparrow$ & $\uparrow$ & $\begin{array}{l}\text { Nosaka et al. } \\
\text { 1996, Nosaka et } \\
\text { al. (2002) }\end{array}$ & $\begin{array}{l}\text { Vandenburgh et } \\
\text { al (1989a) }\end{array}$ & $\begin{array}{l}\text { Cyclical } 20 \% \\
\text { or } 46 \% \text { for up } \\
\text { to } 96 \mathrm{~h} .\end{array}$ \\
\hline $\begin{array}{l}\text { Protein } \\
\text { synthesis }\end{array}$ & $\begin{array}{l}\text { Initial } \downarrow \\
\text { followed by } \\
\uparrow \text { above } \\
\text { baseline } \\
\text { after } \\
\text { exercise }\end{array}$ & $\begin{array}{l}\text { Initial } \downarrow \\
\text { followed by } \\
\uparrow \text { to baseline } \\
\text { after stretch }\end{array}$ & $\begin{array}{l}\text { Bylund-Fellenius } \\
\text { et al. (1984), } \\
\text { Dreyer et al. } \\
\text { (2006) }\end{array}$ & $\begin{array}{l}\text { Atherton et al. } \\
\text { (2009) }\end{array}$ & $\begin{array}{l}\text { Cyclical } 15 \% \text { at } \\
1 \mathrm{~Hz} \text { for } 30 \mathrm{~min}\end{array}$ \\
\hline \multirow[t]{2}{*}{$\mathrm{MHC}$} & \multirow[t]{2}{*}{$\begin{array}{l}\text { Shift MHC } \\
\text { fast } \rightarrow \\
\text { slower } \\
\text { isoforms }\end{array}$} & \multirow[t]{2}{*}{$\begin{array}{l}\text { Shift MHC } \\
\text { fast } \rightarrow \\
\text { slower } \\
\text { isoforms }\end{array}$} & \multirow{2}{*}{$\begin{array}{l}\text { Staron et al } \\
\text { (1994), Adams et } \\
\text { al. (1993), Hather } \\
\text { et al. (1991), } \\
\text { Jansson et al. } \\
\text { (1977), Coggan et } \\
\text { al. (1992), } \\
\text { Allemeier (1994) }\end{array}$} & $\begin{array}{l}\text { Sakiyama et al. } \\
(2005)\end{array}$ & $\begin{array}{l}\text { Cyclical } 15 \% \text { at } \\
0.5 \mathrm{~Hz} \text {, for up } \\
\text { to } 5 \text { days. }\end{array}$ \\
\hline & & & & Kurokawa (2007) & $\begin{array}{l}\text { Cyclical } 15 \% \text { at } \\
0.1 \mathrm{~Hz}, 0.5 \mathrm{~Hz} \\
\text { or } 0.9 \mathrm{~Hz} \text { over } \\
5 \text { days }\end{array}$ \\
\hline \multirow[t]{2}{*}{$\begin{array}{l}\text { mTOR } \\
\text { activation }\end{array}$} & \multirow[t]{2}{*}{$\uparrow$} & \multirow[t]{2}{*}{$\uparrow$} & \multirow{2}{*}{$\begin{array}{l}\text { Leger et al (2006), } \\
\text { Dreyer et al. } \\
\text { (2010). }\end{array}$} & $\begin{array}{l}\text { Hornberger et al } \\
(2004)\end{array}$ & $\begin{array}{l}\text { Cyclical } 15 \% \text { at } \\
1 \mathrm{~Hz} \text { for } 10 \mathrm{~min}\end{array}$ \\
\hline & & & & Sasai et al. (2009) & $\begin{array}{l}\text { Cyclical } 10 \% \text { at } \\
0.16 \mathrm{~Hz} \text { for } 72 \mathrm{~h}\end{array}$ \\
\hline \multirow[t]{2}{*}{$\begin{array}{l}\text { Glucose } \\
\text { metabolism }\end{array}$} & \multirow[t]{2}{*}{$\uparrow$} & \multirow[t]{2}{*}{$\uparrow$} & \multirow[t]{2}{*}{$\begin{array}{l}\text { Rose and Richter } \\
(2005)\end{array}$} & $\begin{array}{l}\text { Hatfaludy et al. } \\
\text { (1989) }\end{array}$ & $\begin{array}{l}\text { Cyclical } 20 \% \text { at } \\
0.25 \mathrm{~Hz} \text { for } 60 \\
\text { sec out of } \\
\text { every } 30 \mathrm{~min} \text {. }\end{array}$ \\
\hline & & & & Iwata et al. (2007) & $\begin{array}{l}\text { Cyclical } 10 \% \text { at } \\
1 \mathrm{~Hz} \text {, for up to } \\
60 \mathrm{~min}\end{array}$ \\
\hline $\begin{array}{l}\text { MMP } \\
\text { expression }\end{array}$ & $\begin{array}{l}\text { Acute } \uparrow \\
\text { MMP9, } \\
\text { chronic } \uparrow \\
\text { MMP2 }\end{array}$ & $\begin{array}{l}\uparrow \mathrm{MMP} 2 \text { at } \\
6 \mathrm{~h} \text { of } \\
\text { stretching }\end{array}$ & $\begin{array}{l}\text { Rullman et al } \\
\text { (2009), Zimowska } \\
\text { et al. (2008). }\end{array}$ & $\begin{array}{l}\text { Auluck et al } \\
\text { (2005). }\end{array}$ & $\begin{array}{l}\text { Rapid ramp } \\
\text { strain: } 7.5 \% \text { or } \\
15 \% \text { for } 6 \mathrm{~h} . \\
\text { Cyclical: } 7.5 \% \\
\text { or } 15 \%, 12 \\
\text { cycles/h }\end{array}$ \\
\hline MRFs & $\begin{array}{l}\uparrow \text { MyoD } \\
\text { early, } \uparrow \\
\text { myogenin } \\
\text { later }\end{array}$ & $\begin{array}{l}\uparrow \text { MyoD and } \\
\text { myf-5 early, } \\
\uparrow \text { myogenin } \\
\text { and MRF-4 } \\
\text { later }\end{array}$ & $\begin{array}{l}\text { Bickel et al. } \\
\text { (2005), McKay et } \\
\text { al. (2008) }\end{array}$ & Abe et al (2009) & $\begin{array}{l}\text { Cyclical } 15 \% \text { at } \\
0.5 \mathrm{~Hz} \text {, for up } \\
\text { to } 48 \mathrm{~h}\end{array}$ \\
\hline
\end{tabular}


Figure 1. Variations in in vitro stretching models. (A) Different axes of strain generation, showing example systems to generate multiaxial and uniaxial strain, (1) Multiaxial stretch using a stretching frame attached to a membrane on which cells are grown, expansion of the frame results in multiaxial strain within the membrane (redrawn from Vandenburgh and Kaufman, 1979). (2) Multiaxial stretch using a vacuum to deform a membrane on which cells are grown. (3) Uniaxial stretch using a stepper motor to increase uniaxial tension on cells seeded within a 3D collagen gel, as described by Cheema et al (2005). The dotted lines in the stretch schematic of each system indicate the original pre-stretch position of the culture. (B) Stretching regimes may involve cyclical loading or ramp loading protocols. 
Figure 1

\section{A Multiaxial stretch}

1. Stretching frame (top view)

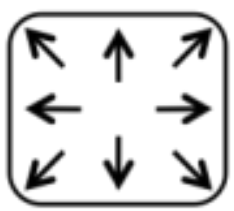

2. Stretch by vacuum (side view)
Resting

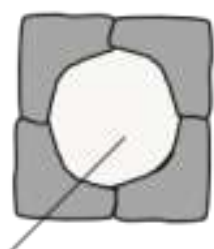

Cells grown on membrane
Stretched

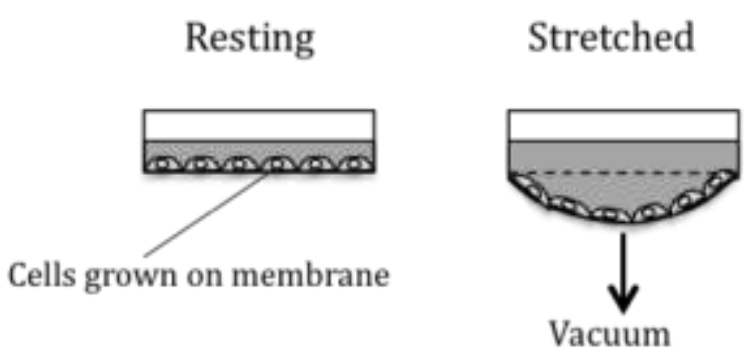

Stretched

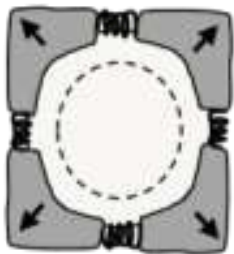

Uniaxial stretch

3. Stretch by stepper motor (top view)

$$
\begin{array}{ll}
\leftarrow & \rightarrow \\
\leftarrow & \rightarrow
\end{array}
$$

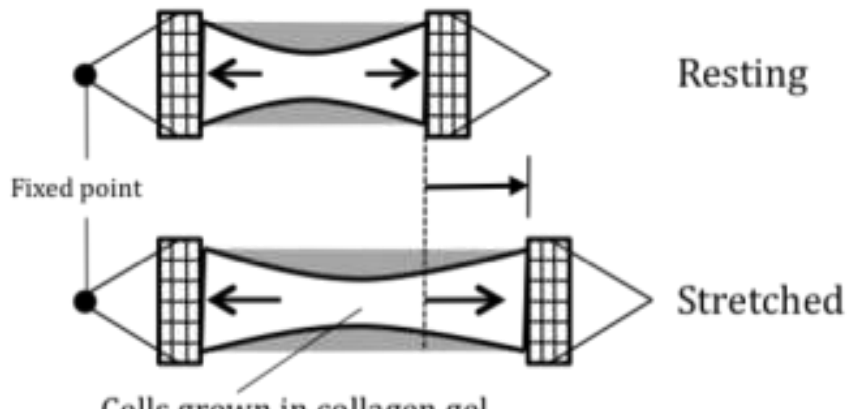

Cells grown in collagen gel

B Cyclical loading

Ramp loading

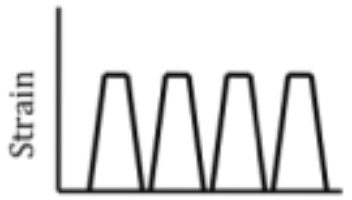

Time

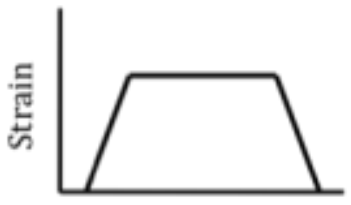

Time 